\title{
Creation of an Engineering Epistemic Frame for K-12 Students (Fundamen- tal)
}

\section{Dr. Tamecia R. Jones, North Carolina State University}

Tamecia Jones is an assistant professor in Technology, Engineering, and Design program of the STEM Education Department at North Carolina State University College of Education with a research focus on K-12 engineering education, assessment, and informal and formal learning environments. She is a graduate of Johns Hopkins, Stanford, and Purdue University. Originally trained as a biomedical engineer, she spent years in the middle school classroom, teaching math and science, and consulting with nonprofits, museums, and summer programs. 


\title{
Creation of an Engineering Epistemic Frame for K-12 Students (Fundamental)
}

\begin{abstract}
In implementation of K-12 engineering education standards, in addition to the professional development teachers need to be trained to prepare students for future engineering careers, assessments must evolve to reflect the various aspects of engineering. A previous research project investigated documentation methods using a variety of media with rising high school juniors in a summer session of a college preparatory program [1]. That study revealed that although students had design journals, storyboards, and traditional assessments, in situ video recordings captured decisions and evolution of projects differently. To further investigate the potential of ongoing interactions as spaces for demonstrating engineering thinking and ideas, a framework was created to analyze in situ video clips. An epistemic frame [2-6] was developed to capture skills, knowledge, identity, values, and epistemologies of engineering relative to K-12 formal and informal spaces. First, this paper will describe the development of an engineering epistemic frame for K-12 students and its synthesis using literature, local contexts, and national policy directives and its application to one pilot set of data as a case study. The context of the case study was final four-week summer session of a college preparatory program of future first generation college students located in a northeastern urban center. The 22 students (14 female, 8 male) were recruited into the college prep program in a school district where $86 \%$ of the students were minority and $75 \%$ low-income. The course was an engineering science course staged as an engineering firm reality television show where students had a weekly challenge that lead to final projects. The project of spotlight for this research was a medical device that would help improve life in some manner involving a prototype and using electric circuits concepts learned over the course of the summer. The frame was applied to 26 video clips to evaluate the kinds of engineering and design knowledge that could be identified and assessed from brainstorm sessions and studio critiques of 9 project groups. The video clips of one group project were coded according to the engineering epistemic frame. Results showed that over half of the students displayed all aspects of the engineering epistemic frame, some students displayed many of the elements of the epistemic frame, and three students exhibited no elements of the epistemic frame. In summary, the first version of the engineering epistemic frame was effective for viewing learning in situ, and brainstorm sessions and studio critiques are spaces where knowledge occurs.

Introduction
\end{abstract}

As engineering expands into K-12 education through curriculum[7, 8] and local[9] and national standards[10], theme and magnet schools[11], and teacher professional development[12, 13], excitement and engagement are improving, but there are still challenges with assessment. As students matriculate through the K-12 system and into college, they are currently assessed via projects, rubrics, and traditional tests. These assessments are shallow in that they do not reflect Pellegrino's priorities of cognition, observation, interpretation, comprehensiveness, coherence, and continuity[14-16]. However, there is potential for innovative assessments that can capture not only content, but skills, and behaviors that are desired in the dynamic, interdisciplinary engineering and design space. There is still a need for an assessment tool that accomplishes the 
following goal: "to make judgments about students' work, inferring from this what they have the capacity to do in the assessed domain, and thus what they know, value, or are capable of doing" [17].

In a research project aimed at observing documentation behavior of students, researchers found from in situ video that student ideas and projects change along a different timeline than the entries in storyboards and journal entries reflect $[1,18]$. The timeline of an average team's documentation behavior is shown in Figure 1, where storyboard and design journals (along with photographs) were the expected receptacles for student thinking. Yet, in situ video clips revealed multiple iterations, represented by purple thought clouds, that showed changes in project trajectories which did not appear in any other of the offered media options. These results showed that educators and researchers were not currently capturing what students were doing beyond what they document or in their interactions.

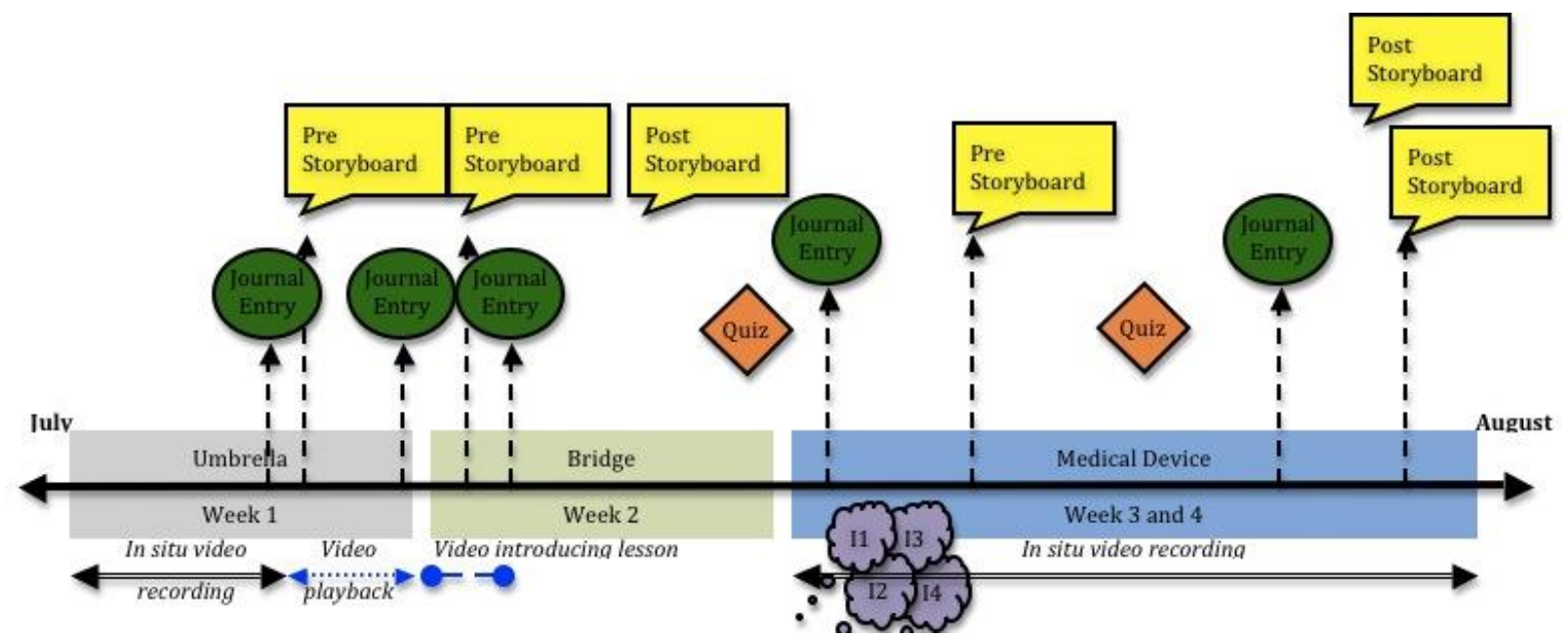

Figure 1 Average documentation behavior of student project groups

This revelation inspired a new line of inquiry to develop a tool that could capture different ways in which students express their knowledge while completing engineering design projects. This lead to the research towards developing a tool which could capture different expressions of engineering knowledge from interactions and conversations.

\section{Literature Review}

Several learning theories were considered in an attempt to assess knowledge and extract behaviors of students within a classroom. They included, but were not limited to, funds of knowledge[19, 20], islands of expertise[21, 22], and communities of practice. Here we highlight the most relevant theories.

An island of expertise [21,22] is a narrow topic that children have interest and engage with it until they have deep and rich knowledge. The islands of expertise develop over time after opportunistic interactions related to the interest. A community of practice [23-25] is 
comprised of a group of people who share language, culture, practices, repertoire of knowledge, and ways of knowing. Individuals within a community of practice express identity and ways of knowing specific to the community. Classrooms are examples of communities of practice in that they have unique belief systems, expectations, and values about what constitutes knowing, so students can develop ways of thinking and identities. Pedagogical praxis posits that different communities of practice have different ways of knowing as they prioritize and value particular information over other information and add to the body of knowledge. Various disciplines will have different epistemic frames because of the differences in their respective components[22, 26, 27].

Epistemic frame[22, 27] theory takes into account all of the ways of being and knowing, skills, knowledge, and community that particular professions have. Islands of expertise necessitate the development of an epistemic frame because knowing what is important, how one determines what is important, and knowing other members of the community value certain knowledge over others is important. Inclusion experiences[28] and virtual internships[29] have provided middle school and high school students with real-world applications and practice in a community of practice of engineers.

Epistemic frames are "collections of skills, knowledge, identities, values, and epistemology that professionals use to think in innovative ways"[28]. Skills are "things that people within the community do" $[28,30]$. Knowledge relates to "the understandings that people in the community share" $[28,30]$. Identity is the way that community member see or might see themselves [28, 30]. Values are the agreed upon beliefs community members hold [28, 30]. Epistemology relates to the justifications, warrants, or rationale that support decisions or actions within the community about what knowledge is true[28, 30]. There are "things to know, ways of knowing them, and ways of finding about them" [31], especially in design and engineering. "Epistemic frame theory suggest that learning to solve complex science, technology, engineering, and math (STEM) problems from being part of a community of practice" [32].

In this exercise, we defined a summer college preparatory engineering and design class as a community of practice where students were performing authentic tasks in which they could develop or expand an epistemic frame. We focused on the interactions that occurred while students completed an engineering design challenge and attempted to apply epistemic frames to assess student ways of being an engineer.

\section{Creation of Engineering Epistemic Frame for K-12 Engineering (EEFK12)}

The engineering epistemic frame for K-12 (EEFK12) was created by synthesizing local frameworks [9], higher education goals, policy directives [33, 34], and relevant literature. The development of the frame occurred using a similar process used by Chesler and colleagues [32] in the development of an online professional practice simulator for freshman undergraduates and Arastoopour and colleagues' virtual internship[29] where they used ABET Criterion 3 as a foundation. Local standards from Massachusetts were used because the curriculum for the summer program was written with them as its foundation and would allow for better alignment with the undergraduate higher education expected outcomes. ABET Criteria 3 present the expected abilities and knowledge undergraduate students should be able to demonstrate upon the 
completion of an accredited undergraduate engineering program. Since its release, The Engineer of 2020 has influenced engineering education as it described what attributes class of 2020 engineering graduates should possess. Literature provided the justification for other elements of the epistemic frame. This engineering epistemic frame (EEFK12) is a synthesis of literature, standards, directives, and outcomes from stakeholders involved in the education and training of engineers from pre-K through undergraduate education. This frame is visually represented in Figure 2.

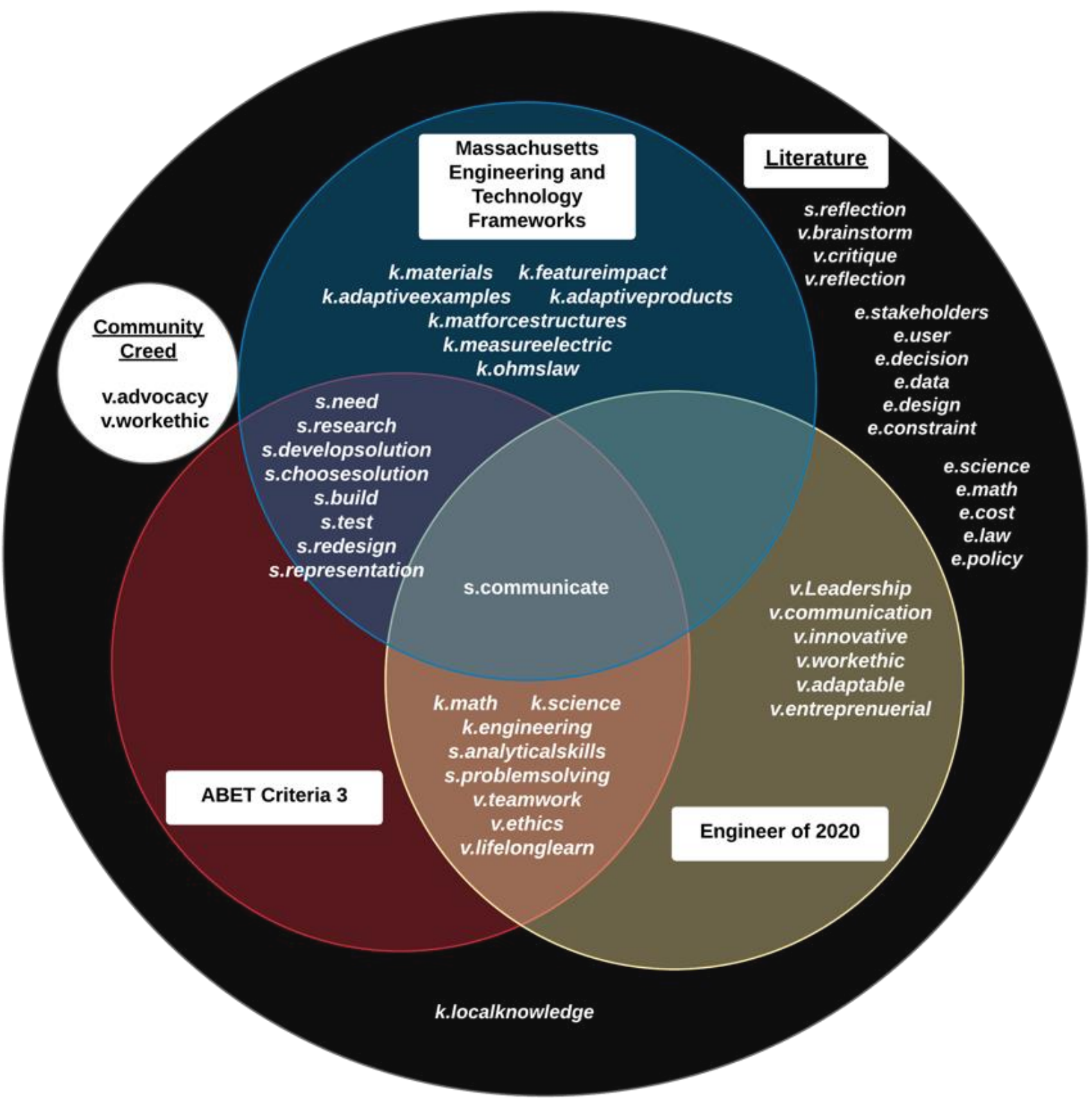

Figure 2 Visual Representation of Relationships between Local Standards, National Directives, Higher Education Outcomes and Literature Synthesized for Engineering Epistemic Frame 
The epistemic frame elements are skills(S), knowledge(K), identity(I), values(V), and epistemology(E), and have been coded as such for analysis. Each parent code (S,K,I,V,E) has a set of sub-codes that allow for macro and micro analysis. The nomenclature for each code is parentcode.subcode, for example k.localknowledge represents the sub-code localknowledge under the parent code K. (but indicated in lowercase). Figure 2 shows how sub-codes are connected to the local (blue circle), national (yellow circle), or higher education frameworks (red circle), and how the community creed (white circle) and research literature (large black circle) are involved in the generation of this engineering epistemic frame, and when codes are the result of overlap between sources [35]. The codes are explained at the macro level with operational definitions and examples in Table 1. The sub-codes are explained in detail following tables by their respective frame $(\mathrm{S}, \mathrm{K}, \mathrm{I}, \mathrm{V}, \mathrm{E})$ element later in this section. For organizational purposes, colors have been associated with each element (skills-yellow, knowledge-green, identity-orange, values-blue, epistemology-gray), and those colors will be a guide throughout the rest of this document.

Table 1 Operational Definitions and Examples of Epistemic Frame Elements

\begin{tabular}{|c|c|c|}
\hline Code & Operational Definition & Examples \\
\hline Skills & $\begin{array}{l}\text { Refers to abilities engineers } \\
\text { display }\end{array}$ & $\begin{array}{l}\text { Brainstorming, identifying } \\
\text { needs }\end{array}$ \\
\hline Knowledge & $\begin{array}{l}\text { Using mathematic or scientific } \\
\text { vocabulary or acknowledging } \\
\text { engineering relationships }\end{array}$ & $\begin{array}{l}\text { Examples include: force, } \\
\text { weight, pressure }\end{array}$ \\
\hline Identity & $\begin{array}{c}\text { References or presents playing } \\
\text { roles }\end{array}$ & Designer, user \\
\hline Values & $\begin{array}{l}\text { Refers to concepts or behaviors } \\
\text { important to engineers or their } \\
\text { practice }\end{array}$ & $\begin{array}{l}\text { Concerned about stakeholders } \\
\text { in implementation of design, } \\
\text { brainstorming multiple ideas, } \\
\text { giving constructive critique }\end{array}$ \\
\hline Epistemology & $\begin{array}{l}\text { References justifications for } \\
\text { decisions or actions in the } \\
\text { engineering profession }\end{array}$ & $\begin{array}{l}\text { Making decisions based on } \\
\text { cost or legality, data, or testing; } \\
\text { using knowledge of math } \\
\text { equations or scientific theory in } \\
\text { design, evaluating tradeoffs }\end{array}$ \\
\hline
\end{tabular}

In constructing the engineering epistemic frame, the first step was to highlight the local standards and see where in the epistemic frame they align. Since the curriculum units were limited to certain standards, those were included, and the state-approved engineering design process [9], shown in Figure 3, was broken down into 8 skills. Those standards were distributed appropriately and resulted in 10 skills, and 10 expressions of knowledge, shown in Table 2. 


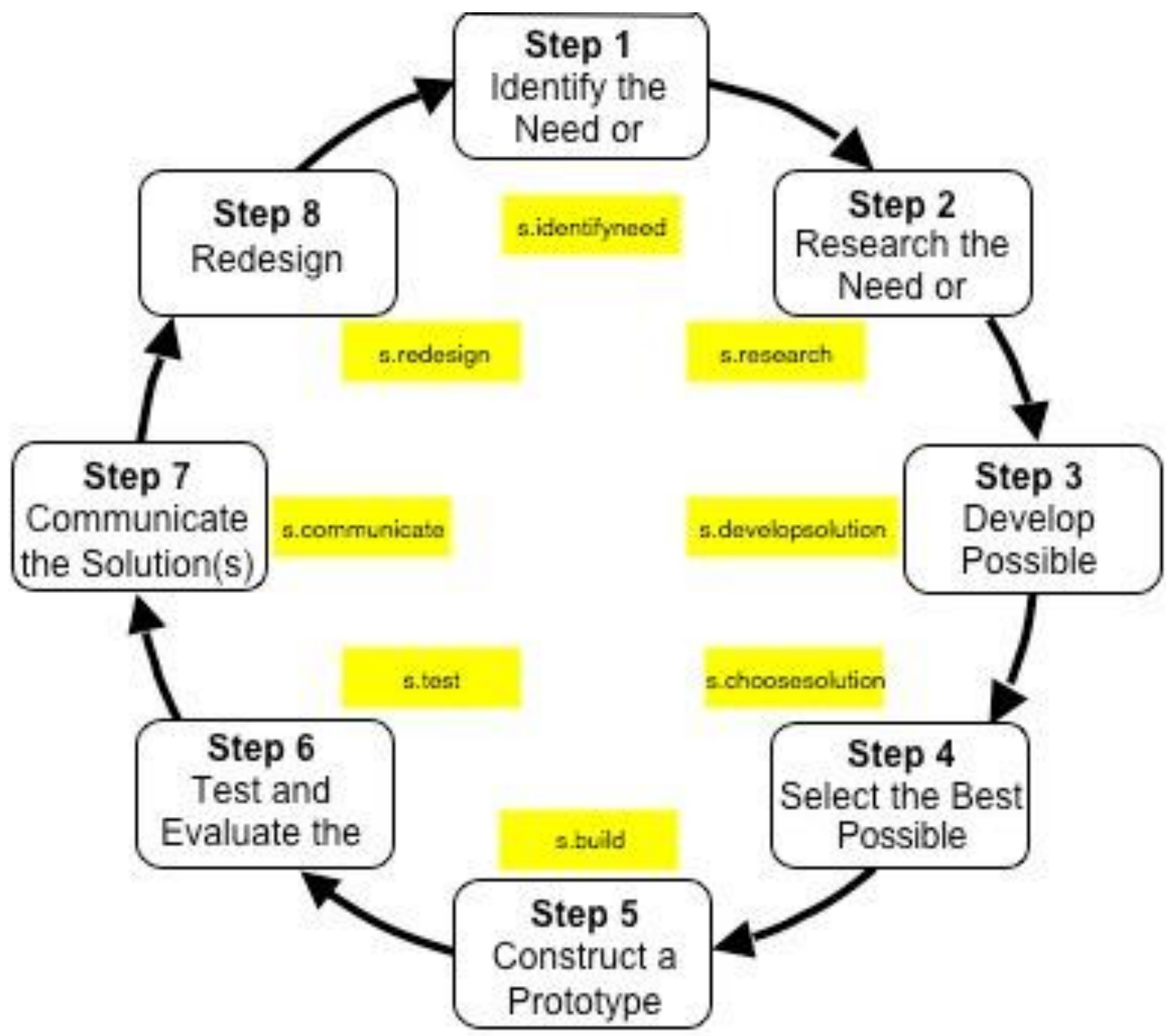

Figure 3 Massachusetts K-12 Engineering Design Process.

Table 2 Skills and Knowledge alignment with Massachusetts Frameworks

\begin{tabular}{|c|c|c|} 
Label & \multicolumn{2}{|c|}{ Framework } \\
ED1 & $\begin{array}{r}\text { 2.1 Identify and explain the steps of the engineering design } \\
\text { process, i.e., identify the need or problem, research the } \\
\text { problem, develop possible solutions, select the best possible } \\
\text { solution(s), construct a prototype, test and evaluate, } \\
\text { communicate the solution(s), and redesign. }\end{array}$ & $\begin{array}{c}\text { Sub-Code } \\
\text { s.developsolution } \\
\text { s.choosesolution, } \\
\text { s.build, s.test } \\
\text { s.communicate, } \\
\text { s.redesign }\end{array}$ \\
\hline ED2 & $\begin{array}{r}2.2 \text { Demonstrate methods of representing solutions to a } \\
\text { design problem, e.g., sketches, orthographic projections, } \\
\text { multi-view drawings. }\end{array}$ & s.representation \\
\hline ED3 & 2.3 Describe and explain the purpose of a given prototype. & s.communicate \\
\hline ED4 & $\begin{array}{r}\text { 2.4 Identify appropriate materials, tools, and machines } \\
\text { needed to construct a prototype of a given engineering } \\
\text { design. }\end{array}$ & k.materials \\
\hline
\end{tabular}




\begin{tabular}{|c|c|c|}
\hline ED5 & $\begin{array}{l}\text { 2.5 Explain how such design features as size, shape, } \\
\text { weight, function, and cost limitations would affect the } \\
\text { construction of a given prototype. }\end{array}$ & k.featureimpact \\
\hline CT1 & $\begin{array}{l}5.2 \text { Identify and describe three major types of bridges (e.g., } \\
\text { arch, beam, and suspension) and their appropriate uses (e.g., } \\
\text { site, span, resources, and load)Design and construct a } \\
\text { bridge following specified design criteria (e.g., size, } \\
\text { materials used). Test the design for durability and structural } \\
\text { stability. }\end{array}$ & k.bridgetype \\
\hline CT2 & $\begin{array}{l}\text { 5.3 Explain how the forces of tension, compression, } \\
\text { torsion, bending, and shear affect the performance of } \\
\text { bridges. }\end{array}$ & k.bridgeforces \\
\hline CT3 & $\begin{array}{l}\text { 5.4 Describe and explain the effects of loads and structural } \\
\text { shapes on bridges. }\end{array}$ & k.bridgeeffects \\
\hline BT1 & $\begin{array}{l}\text { 7.1 Explain examples of adaptive or assistive devices, e.g., } \\
\text { prosthetic devices, wheelchairs, eyeglasses, grab bars, } \\
\text { hearing aids, lifts, braces. }\end{array}$ & k.adaptiveexamples \\
\hline BT2 & $\begin{array}{l}\text { 7.2 Describe and explain adaptive and assistive } \\
\text { bioengineered products, e.g., food, bio-fuels, irradiation, } \\
\text { integrated pest management. }\end{array}$ & k.adaptiveproducts \\
\hline BT3 & $\begin{array}{l}\text { Brainstorm and evaluate alternative ideas for an adaptive } \\
\text { device that will make life easier for a person with a } \\
\text { disability, such as a device that picks up objects from the } \\
\text { floor. }\end{array}$ & $\begin{array}{r}\text { No sub-code, } \\
\text { Project objective }\end{array}$ \\
\hline AF1 & $\begin{array}{l}2.2 \text { Distinguish among tension, compression, shear, and } \\
\text { torsion, and explain how they relate to the selection of } \\
\text { materials in structures. (pg 92) }\end{array}$ & k.matforcestructures \\
\hline AF2 & $\begin{array}{l}\text { 5.1 Explain how to measure and calculate voltage, current, } \\
\text { resistance, and power consumption in a series circuit and in } \\
\text { a parallel circuit. Identify the instruments used to measure } \\
\text { voltage, current, power consumption, and resistance. }\end{array}$ & k.measureelectric \\
\hline AF3 & $\begin{array}{l}\text { 5.3 Explain the relationships among voltage, current, and } \\
\text { resistance in a simple circuit, using Ohm's law. }\end{array}$ & k.ohmslaw \\
\hline
\end{tabular}

After the standards were distributed, a review of higher education and policy directives was completed. Historically a trailblazer in first year engineering and the transition from high school to undergraduate engineering programs, Purdue University engaged ABET criteria 3 and Engineer of 2020 attributes, integrated them, and established twenty target attributes of "renaissance engineers" which was approved by their faculty and categorized as abilities, knowledge areas, and qualities[36] and are shown in Figure 4. 


\begin{tabular}{|l|}
\hline \multicolumn{1}{|c|}{ Abilities } \\
\hline - Leadership \\
- Teamwork \\
- Communication \\
-Decision-making \\
- Recognize and manage \\
change \\
- Work effectively in \\
diverse \& multicultural \\
environments \\
- Work effectively in global \\
engineering profession \\
- Synthesize engineering, \\
business, and societal \\
perspectives \\
\hline
\end{tabular}

\begin{tabular}{l} 
Knowledge Areas \\
\hline • Science \& Math \\
• Engineering \\
fundamentals \\
-Analytical skills \\
• Open-ended design \& \\
problem solving skills \\
-Multidisciplinary \\
within and beyond \\
engineering \\
-Integration of \\
analytical, problem \\
solving, and design \\
skills \\
\hline
\end{tabular}

\begin{tabular}{|l|}
\hline \multicolumn{1}{|c|}{ Qualities } \\
\hline •Innovative \\
-Strong work ethic \\
- Ethically responsible in \\
a global, social, \\
intellectual, and \\
technological context \\
-Adaptable in a \\
changing environment \\
•Entrepreneurial and \& \\
intrapreneurial \\
•Curious and persistent \\
learners
\end{tabular}

Figure 4. Purdue University Engineer of 2020 Abilities, Knowledge Areas, and Qualities

Because these target attributes were more detailed and expansive, had a greater potential for assessment because of their specificity, and were more aligned with many of the S,K,I,V,E elements of the epistemic frame than the attributes proposed by the National Academy of Engineering, this engineering epistemic frame includes more than the ten NAE Engineer of 2020 attributes. The alignment of the Purdue Engineer of 2020 Target Attributes with the epistemic frame elements is shown in Figure 5.

Skills (S)

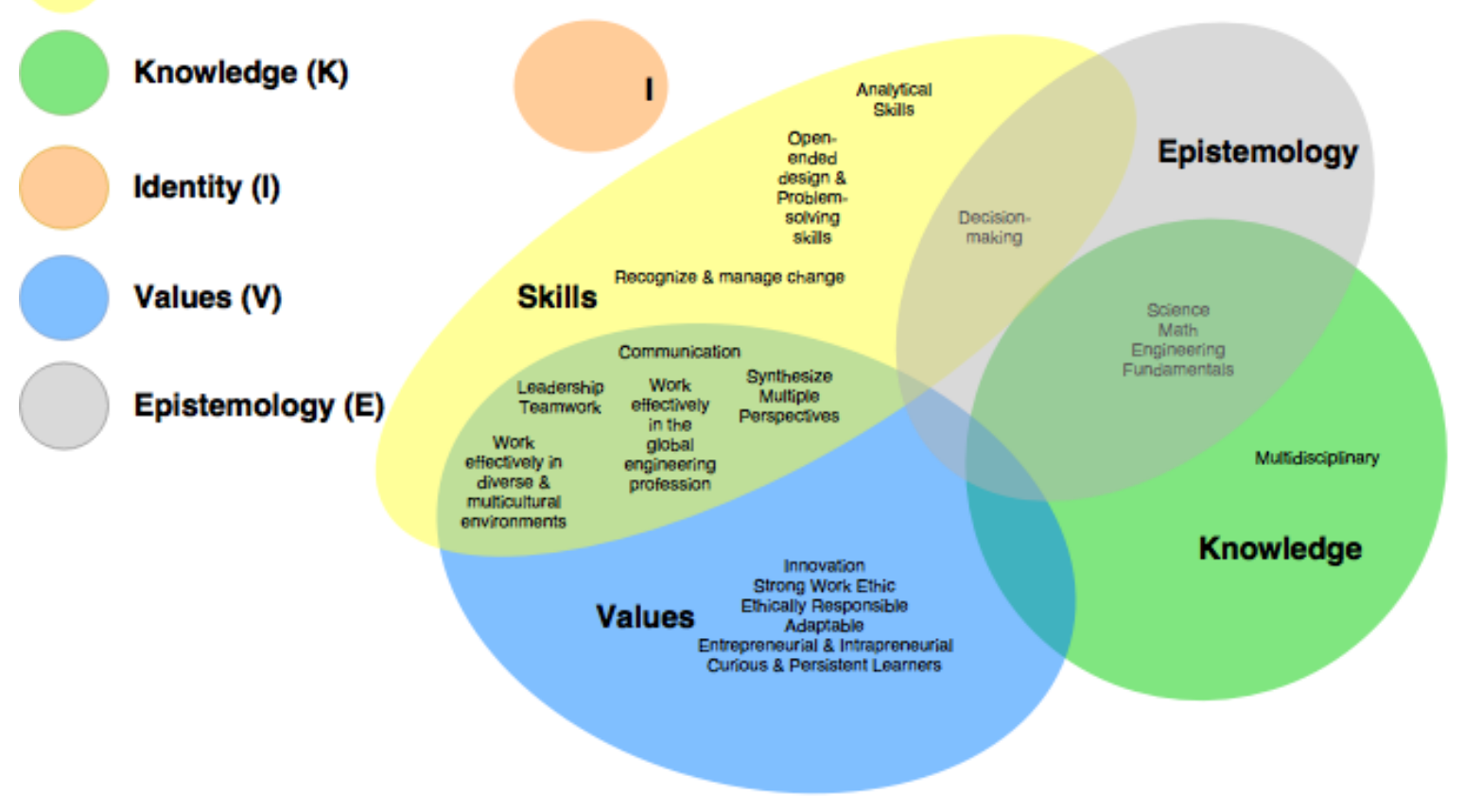

Figure 5 Alignment of Purdue Engineer of 2020 Attributes with Elements of Epistemic Frame 
All decisions about where to place an attribute when it could exist in multiple epistemic elements were made based on 1) operational definitions of skills, knowledge, identity, values, and epistemology and 2) how local standards would prioritize the sub-code. For example, leadership and teamwork were not listed in those local Massachusetts standards as skills that are traditionally assessed, so those two attributes were explicitly assessed as a value because they are behaviors. When and if a sub-code appears in more than one epistemic frame element and appear to be duplicates, the nuances of the differences are explained with examples in the epistemic frame element tables [35].

Some of the codes from

Purdue/Engineer of 2020 did not apply to this research context, so they were not included in the epistemic frame. They were Work effectively in the global engineering profession and Work effectively in diverse and multicultural environments. Both of these codes could, however, be assessed if a K-12 program included study abroad or service learning.

Having reviewed standards and policy directives, the next stage was to review the Accreditation Board for Engineering and Technology criteria for students completing college and integrate those criteria into the appropriate element of the epistemic frame. The ABET criteria align most closely with only three elements of the five elements of the emerging epistemic frame. Those elements were skills, knowledge, and values. This alignment is represented visually in Figure 6. There are eleven outcomes (a-k) included in Criteria 3, and the colors (yellow, green, orange, blue, and gray) associated with the elements of the epistemic frame are indicated in the legend. Since ABET Criteria 3 did not align to identity or epistemology, none of the criteria are highlighted orange or gray.

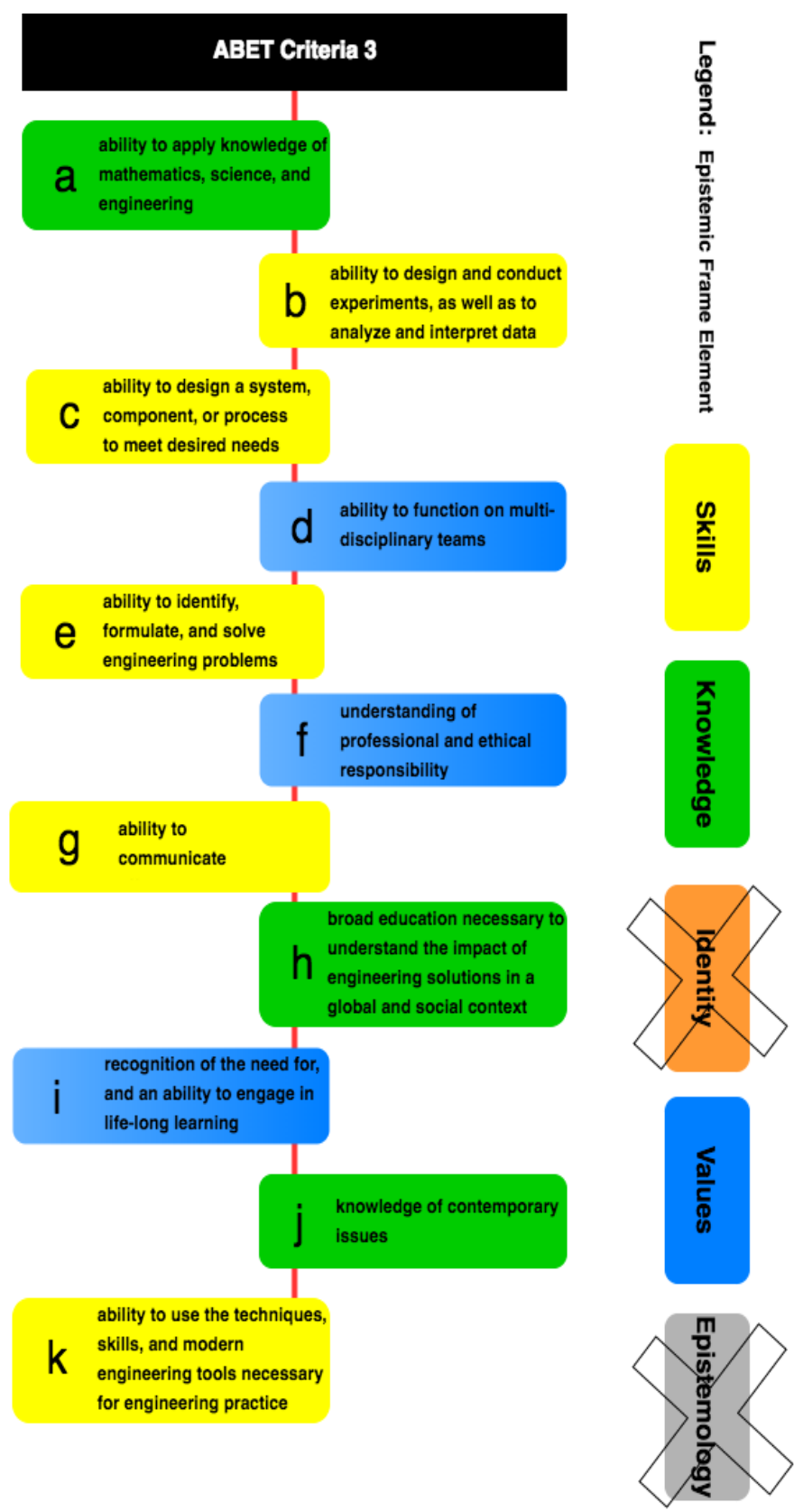

Figure 6 Alignment of ABET Criteria 3 with epistemic elements 
After reviewing standards, policy directives, and higher educational outcomes, the next considerations included community context and literature to fill in any gaps in the identity, values, and epistemology elements of the frame. The identity (I) sub-codes were based on students' expression as a designer or a user when they communicated within groups and to the entire class. Values (V) sub-codes were extracted from Engineer of 2020[33], ABET Criteria 3, the community creed of the college preparatory program, and relevant design education literature[37-42]. A few of the values sub-codes were selected because the community of the college preparatory program had established values around hard work and advocacy[35]. Epistemology (E) sub-codes describe actions, behaviors, or any arguments that explain and justify routines in the engineering and design discipline. Examples of the expected routines include, but are not limited to, collecting and evaluating data inspired and validated by mathematical and scientific principles, cost analysis, public policy, legality[43], user- and human-centered design[44-46], empathy[47], and design across contexts and age groups[48-63].

Finally, the engineering epistemic frame for K-12 students (EEFK12) emerged with 48 sub-codes across the five epistemic frame elements of skills(12), knowledge(12), identity(3), values(10), and epistemology(11). The 48 sub-codes are listed below:

- $\quad$ s.need

- s.research

- s.developsolution

- s.choosesolution

- s.build

- s.test

- s.communicate

- s.redesign

- s.representation

- $\quad$ s.analyticalskills

- s.problemsolving

- s.reflection

- k.localknowledge

- k.materials

- k.featureimpact

- k.adaptiveexamples

- k.adaptiveproducts
- k.matforcestructures

- k.measureelectric

- k.ohmslaw

- k.externalimpact

- k.math

- k.science

- k.engineering

- i.designer

- i.user

- i.scholar

- v.teamwork

- v.communication

- v.innovative

- v.workethic

- v.ethics

- v.lifelonglearn

- v.advocacy
- v.brainstorm

- v.critique

- v.reflection

- e.science

- e.math

- e.cost

- e.law

- e.policy

- e.stakeholders

- e.user

- e.decision/evaluating tradeoff

- e.data

- e.design/engineering

- e.constraint

When sub-codes appear to be duplicates, the nuances are explained and described in context with examples in [35]. The engineering epistemic frame was reviewed by two external parties and revised before it was applied to video clip transcripts.

\section{Research Context}

The research site was a small, private college in an urban center where, College Next, a college preparatory program for local high school students was sponsored. Eligible recruits for the program were potential first-generation students from four partner high schools and middle schools within the urban school district, where $86 \%$ of the students were minority and $75 \%$ low- 
income. There were 22 (14 females, 8 males) rising seniors from a range of public and charter schools.

The course was an engineering science course staged as an engineering firm reality television show where students had a weekly challenge that lead to final projects. The project of spotlight for this research was a medical device that would help improve life in some manner involving a prototype and using electric circuits concepts learned over the course of the summer.

The data collection process involved spontaneous video recordings conducted by the students and instructor of brainstorm sessions, construction sessions, and test day. Though the project was presented to students to mimic a reality television show, neither studio cameras nor camerapersons were assembled to collect data. All of the images were participant-generated [64], captured by the instructor, program director, or students themselves. These images, still or moving, were descriptive and illustrative artifacts [65] from student decisions and expressions as they or the researcher used the camera as a tool. Though the data was collected to observe documentation behaviors, the overarching research question for this project was:

What kinds of engineering and design knowledge can be identified and assessed via video clips of brainstorm sessions and studio critiques using elements of an engineering epistemic frame?

Studio critiques [66-70] and brainstorm[71, 72] sessions were selected because of their prominence in design and engineering. During brainstorm sessions and studio critiques, there is potential to see individual, group, and class dynamics and assess on multiple levels. There were 26 student collected video clips reviewed. For the pilot study, the clips were coded by one researcher, and when there was a question about a code or a duplicate code, a second researcher provided review. Below is an example of a coded excerpt:

\begin{tabular}{|c|c|}
\hline Excerpt & Sub-codes \\
\hline $\begin{array}{l}\text { "We designed something called, "the neck-ma", because when trying } \\
\text { to think of what we want to do we thought whether we were going } \\
\text { to do kids or adults, and we said kids }{ }^{4} \text {. We realized a lot of kids } \\
\text { have asthma, and a lot of kids don't know where their asthma } \\
\text { pump }{ }^{6} \text { is, or they lose it. }{ }^{1} \text { We thought it'd be better if they had it } \\
\text { located on them at all times so there'd be less tragedies when it } \\
\text { comes to asthma attacks, and stuff, or the neck-ma. We called it } \\
\text { neck-ma, because it's a combination of a necklace and an asthma } \\
\text { pump. }\end{array}$ & $\begin{array}{l}\text { s.need }^{1} \text {, } \\
\text { s.developsolution }^{2} \text {, } \\
\text { s.choosesolution }^{3,} \\
\text { e.decision }^{4} \\
\text { v.innovative }^{5}, \\
\text { k.science }^{6}\end{array}$ \\
\hline $\begin{array}{l}\text { "Dude, you have a cast. You can't just slide the cast off and then put } \\
\text { it back on when you are warm?" }\end{array}$ & $\begin{array}{l}\text { s.problemsolving, } \\
\text { k.localknowledge, } \\
\text { i.user, e.constraint }\end{array}$ \\
\hline $\begin{array}{l}\text { When this muscle stretches the one in the back contracts }{ }^{1} \text {. Like this } \\
\text { muscle and this muscle move forward it contracts, and then that's going } \\
\text { to activate something in the other side where your leg is like cut. That } \\
\text { is going to make some mechanical stuff like go forward and } \\
\text { backward, just like a person walks. }\end{array}$ & $\begin{array}{l}\text { k.science } \\
\text { k.engineering }^{2} \\
\text { s.analyticalskills, } \\
\text { s.developsolution, }\end{array}$ \\
\hline
\end{tabular}


Results

This version of the EEFK12 was effective in revealing many of the elements of an engineering epistemic frame, based on analysis of the in situ video clips from brainstorm sessions and studio critiques. In Figure 7, each SKIVE element is distinguished by color (skills (yellow), knowledge (green), identity (orange), values (blue), and epistemology (grey)) with subcodes delineated. Of the 48 codes investigated, v.teamwork $(n>55)$ and k.engineering $(n=55)$ were the most prominent sub-codes present, but the skills element was the most prominent overall element demonstrated by the students in these clips because the majority of its codes were witnessed.

On the individual student level, approximately half of the students exhibited all of the elements of the epistemic frame, some students exhibited many but not all of the epistemic frame elements, and there were three students that did not express any of the elements of the engineering epistemic frame.(Table 3). Of the students who did not express any of the elements of the EEFK12, this is often because they often spoke more comfortably in their original language and their statements could not be coded or because they were shy and did little talking in group presentations or in front of the camera.

Table 3 Demonstration of Engineering Epistemic Frame Elements

\begin{tabular}{|l|l|l|l|l|l|}
\hline & S & K & I & V & E \\
\hline Uriel & & & & & \\
\hline Melanie & & & & & \\
\hline Rae & & & & & \\
\hline Simone & & & & & \\
\hline Optimus & & & & & \\
\hline Noah & & & & & \\
\hline Victoria & & & & & \\
\hline Tiaje & & & & & \\
\hline Paola & & & & \\
\hline Leilani & & & & & \\
\hline Quincy & & & & \\
\hline Gavin & & & & \\
\hline Joaquim & & & & \\
\hline Darren & & & & \\
\hline Caitlyn & & & & \\
\hline Honore & & & & \\
\hline Fabienne & & & & \\
\hline Breilyn & & & & \\
\hline Inti & & & & \\
\hline Kingston & & & & \\
\hline Elan & & & & \\
\hline
\end{tabular}




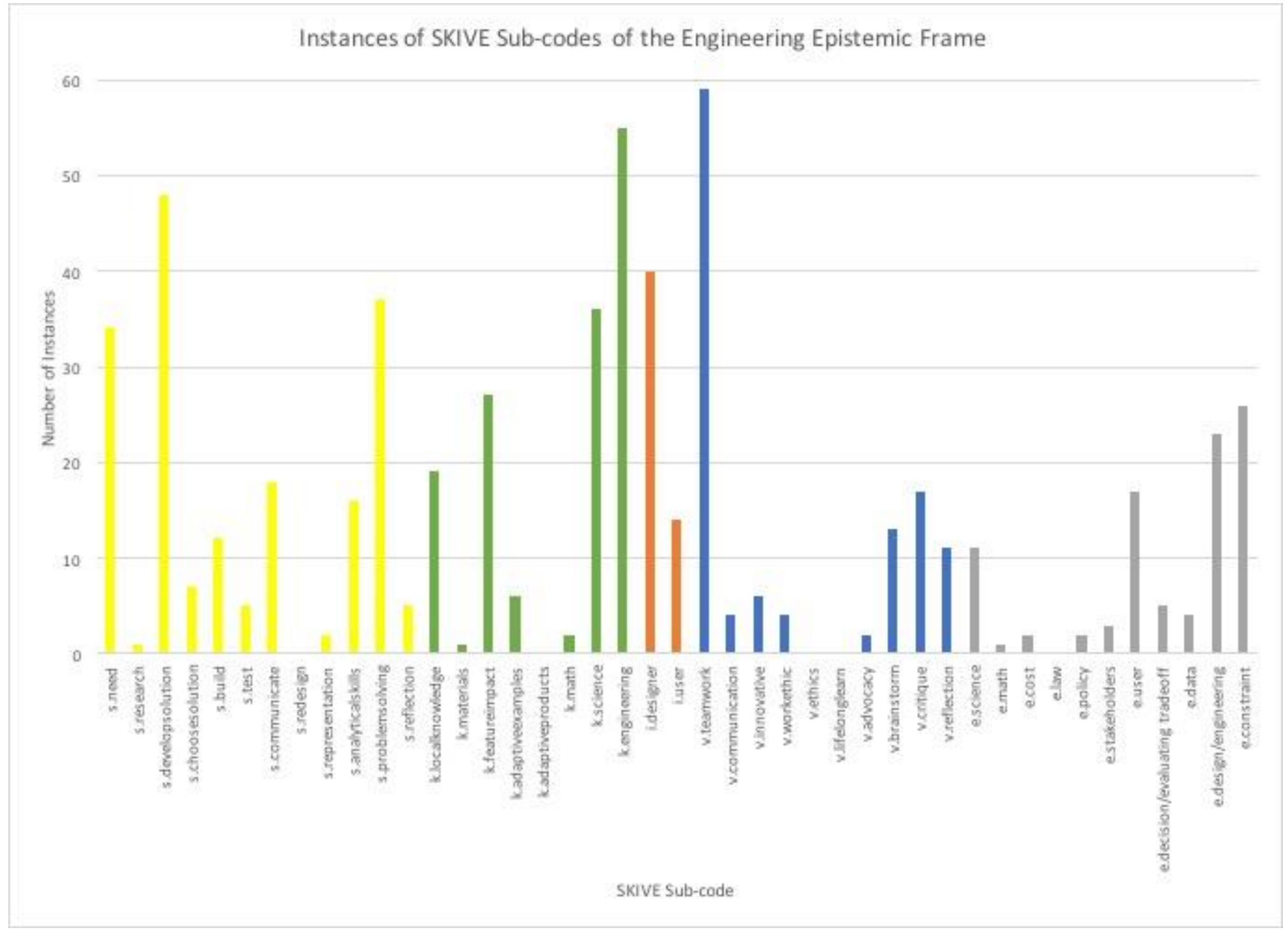

Figure 7 Summary of all instance of engineering epistemic frame sub-codes 


\section{Discussion}

To promote research integrity, the author must disclose nuances to the research that impacted the research. The EEFK12 must be tested again with new data because the data used was collected for a previous research project, and expected challenges of methodological integrity [73] and quality of research exist. Since the researcher was also the instructor as data was collected although for different purposes, this poses a threat to validity theoretically, procedurally, communication-wise, pragmatically, and ethically[74-76].

From preliminary application, this engineering epistemic frame shows potential for revealing skills in interactions and conversations that are expressed differently or less frequently captured on traditional paper methods. Specifically, it has the potential to capture values or epistemology that are not currently assessed in K-12 students. Another advantage of this engineering frame is that it has potential to be flexible across K-12 grades and across formal or traditional settings, but it must (and can) be adapted appropriately to the context or discipline as the size of the epistemic frame with sub-codes could become unwieldy. In lower grades, macro levels of skills, knowledge, identity, values, and epistemology can be assessed, while as content and developmental abilities change, sub-codes can be added to the frame for upper elementary, middle, and high school students. This engineering epistemic frame can be used to assess individuals, project groups, class sessions, or courses using additional techniques such as epistemic network analysis[35, 43]. Epistemic network analysis quantifies the process into network models at individual, group, and class level. Those preliminary results applied to the same case study will be published separately. A disadvantage to this engineering epistemic frame is that until it is packaged differently in combination with video clips, it can be timeconsuming for teachers to use because of the qualitative coding that must take place. Another disadvantage of this engineering epistemic frame is that coders will have to be trained well since there are nuances in sub-codes. In its current state and as it evolves, the engineering epistemic frame (EEFK12) needs to go through interrater reliability and validity checks for various contexts and multiple grade levels on larger data sets. Streamlining this process for efficiency and ease of use for stakeholders beyond researchers and offering various forms of the engineering epistemic frame for more contexts is a goal of the researcher.

\section{Conclusion}

We know that we can assess content knowledge in pre-college engineering, but we have yet to perfect measuring other competencies and ways of being important to the discipline. The overarching goal of this research project was to generate an engineering epistemic frame that would be appropriate for K-12 engineering students and contexts, and to apply it to nontraditional spaces of student interactions. It was applied with high school students in an informal summer program. The development of the engineering epistemic frame for K-12 education (EEFK12) integrated goals from higher education and policy stakeholders so that as educators and researchers move upstream to educate younger and younger students, there is more continuity and alignment and innovation in assessment. Though the EEFK12 shows promise for capturing various ways of knowing, it does have a need for revision and updating. This version of the EEFK12 (EEFK12.1) was based on local standards of a particular state, but has been 
aligned with the Next Generation Science Standards [10]to show robustness [35]. This version also can be expanded to include multiple, age-appropriate versions of the design process[77] to be sensitive to development stages across age groups. This version of the EEFK12 also had a more shallow coverage of the identity element when compared to the other epistemic frame elements. This is due to a choice for limiting the scope of the project and smaller body of literature for K-12 engineering identity. The next iteration of the frame (EEFK12.2) will be updated to include NGSS goals and be tested across the K-12 spectrum with elementary, middle, and high school students. Even in its infant stages, the EEFK12 has potential to broaden assessment lenses and include opportunities for assessing what the engineering discipline values while honoring what K-12 traditionally assesses, benefitting students, teachers, and improving continuity along the K-12 continuum.

\section{References}

[1] T. R. Jones, M. Cardella, and S. Purzer, "Using and Comparing Paper and Media to Improve Student Reflection in Science and Design Courses," presented at the National Association for Research in Science Teaching, Indianapolis, IN, Feb 24, 2012, Article.

[2] G. Arastoopour, N. C. Chesler, D. W. Shaffer, and Z. Swiecki, "Epistemic network analysis as a tool for engineering design assessment," presented at the 2015 ASEE Annual Conference \& Exposition, Seattle, Washington, 2015, June.

[3] N. C. Chesler, A. R. Ruis, W. Collier, Z. Swiecki, G. Arastoopour, and D. W. Shaffer, "A novel paradigm for engineering education: virtual internships with individualized mentoring and assessment of engineering thinking.," Journal of Biomechanical Engineering, vol. 137, no. 2, p. 24701 (8), 2015, doi: 10.1115/1.4029235.

[4] R. Matwyczuk, "Epistemic Learning: Game Programming Learned from the Lens of Professionals," Master of Education, Department of Curriculum, Teaching, and Learning, University of Manitoba, Winnipeg, 2013.

[5] M.-G. N. Svarovsky, "Unpacking the Digital Zoo: An analysis of the learning processes within an engineering epistemic game," PhD Doctoral, Educational Psychology, University of Wisconsin-Madison, ProQuest Dissertations \& Theses Global, 3399952 , 2009. [Online]. Available: https://search-proquestcom.ezproxy.lib.purdue.edu/docview/305030482? accountid=13360

[6] S. F. Wolf, L. Doughty, P. W. Irving, E. C. Sayre, and M. D. Caballero, "Just Math: A new epistemic frame," in PERC Proceedings, 2014.

[7] R. H. Crawford, K. L. Wood, M. L. Fowler, and J. L. Norrell, "An engineering design curriculum for the elementary grades," Journal of Engineering Education, vol. 83, no. 2, pp. 172-181, 1994.

[8] S. e. Purzer, J. Strobel, and M. E. Cardella, Engineering in pre-college settings : synthesizing research, policy, and practices. West Lafayette, Indiana : Purdue University Press, 2014.

[9] (2006). Massachusetts Science and Technology/Engineering Curriculum Framework. [Online] Available: www.doe.mass.edu

[10] NGSS Lead States. "Next Generation Science Standards: For States, By States." Achieve, Inc. http://www.nextgenscience.org/ (accessed May 31, 2013). 
[11] E. A. Parry and E. G. Hardee, "DEVELOPING ELEMENTARY ENGINEERING SCHOOLS: FROM PLANNING TO PRACTICE AND RESULTS," presented at the American Society for Engineering Education Annual Conference \& Exposition, San Antonio, TX, Apr 18, 2012.

[12] M. S. Zarske, J. F. Sullivan, L. E. Carlson, and J. L. Yowell, "Teachers teaching teachers: Linking K-12 engineering curricula with teacher professional development," in Proceedings of the 2004 American Society for Engineering Education Annual Conference \& Exposition, 2004: American Society of Engineering Education.

[13] D. Duncan-Wiles and T. R. Jones, "Work in Progress: Changes in Elementary Teachers" Noticing of Engineering Pre/Post Professional Development with Engineering," Proc ASEE/IEEE ..., 2012.

[14] J. Pellegrino, N. Chudowsky, and R. Glaser, Eds. Knowing What Students Know: The Science and Design of Educational Assessment. Washington, DC: National Academy Press, 2001.

[15] J. W. Pellegrino, "Rethinking and Redesigning Curriculum, Instruction and Assessment:What Contemporary Research and Theory Suggests," National Center on Education and the Economy, Washington, DC, Word Document Nov 022006.

[16] J. W. Pellegrino and E. S. Quellmalz, "Perspectives on the Integration of Technology and Assessment," Journal of Research on Technology in Education, Article vol. 43, no. 2, pp. 119-134, 2010.

[17] G. Joughin, Assessment, Learning and Judgement in Higher Education. Dordrecht: Springer Netherlands, 2008.

[18] T. R. Jones, S. Purzer, and M. Cardella, "The Reality Show of a High School Science, Engineering, and Design Course: Observing Documentation and Communication Patterns to Inform Pedagogy and Assessment," presented at the 119th American Society for Engineering Education Annual Conference \& Exposition, San Antonio, TX, Apr 18, 2012, Article.

[19] L. C. Moll, C. Amanti, D. Neff, and N. Gonzalez, "Funds of knowledge for teaching: Using a qualitative approach to connect homes and classrooms," Theory Into Practice, vol. 31, no. 2, pp. 132-141, 1992.

[20] A. C. Barton and E. Tan, "Funds of knowledge and discourses and hybrid space," (in English), Journal of Research in Science Teaching, vol. 46, no. 1, pp. 50-73, Feb 2009, doi: 10.1002/tea.20269.

[21] K. Crowley and M. Jacobs, "Building islands of expertise in everyday family activity," in Learning conversations in museums, G. Leinhardt, K. Crowley, and K. Knutson Eds. Mahwah, NJ: Lawrence Erlbaum, 2002, ch. 10, pp. 333-356.

[22] D. W. Shaffer, "Epistemic frames and islands of expertise: Learning from infusion experiences," in Proceedings of the 6th International Conference on Learning sciences, Santa Monica, CA, 2004: International Society of the Learning Sciences, pp. 473-480.

[23] J. Lave and E. Wenger, Situated learning : legitimate peripheral participation. Cambridge [England] ; New York: Cambridge University Press, 1991.

[24] E. Wenger, "Communities of Practice: Learning as a Social System," Systems Thinker, vol. 9, no. 5, 1998.

[25] E. Wenger, "Communities of practice: A Brief Introduction,"

[26] D. W. Shaffer, "Pedagogical praxis: The professions as models for post-industrial education.," Teachers College Record, vol. 106, no. 7, pp. 1404-1421, 2004. 
[27] D. W. Shaffer, "Epistemic frames for epistemic games," Computers \& Education, vol. 46, no. 3, pp. 223-234, 2006, doi: 10.1016/j.compedu.2005.11.003.

[28] D. W. Shaffer, How computer games help children learn, 1st ed.. ed. New York: Palgrave Macmillan, 2006.

[29] G. Arastoopour, D. W. Shaffer, Z. Swiecki, A. R. Ruis, and N. C. Chesler, "Teaching and assessing engineering design thinking with virtual internships and epistemic network analysis," International Journal of Engineering Education, vol. 32, no. 3, (B), pp. 14921501, 2016.

[30] A. Rupp et al., "Modeling Learning Progressions In Epistemic Games With Epistemic Network Analysis: Principles For Data Analysis And Generation," in Learning Progrogressions in Science (LeaPS) Conference, Iowa City, IA, 2009.

[31] N. Cross, "Designerly ways of knowing," Design Studies, vol. 3, no. 4, pp. 221-227, 1982, doi: papers3://publication/uuid/F66AE595-8DD8-47ED-8E7C-F91CFE9FCE7E.

[32] N. C. Chesler, G. Argastoopour, C. M. D'Angelo, E. A. Bagley, and D. W. Staffer, "Design of professional practice simulator for educating and motivating first-year engineering students," Advances in Engineering Education, vol. 3, no. 3, pp. 1-29, 2013.

[33] National Academy of Engineering, The Engineer of 2020: Visions of Engineering in the New Century. Washington, DC: National Academies Press, 2004, pp. 1-23.

[34] National Research Council, Educating the Engineer of 2020: Adapting Engineering Education to the New Century. Washington, DC: The National Academies Press, 2005.

[35] T. Jones, "Developing and Testing a K-12 Engineering Epistemic Frame to Uncover Engineering in the Interactions of a High School Summer Session," Doctor of Philosophy, Engineering Education, Purdue University, West Lafayette, IN, 10790842 , 2018.

[36] Purdue University. "Engineer of 2020 Initiative." Purdue University. https://engineering.purdue.edu/Engr/Academics/Engineer2020 (accessed January 4, 2015).

[37] S. R. Daly, R. S. Adams, and G. M. Bodner, "What Does it Mean to Design? A Qualitative Investigation of Design Professionals' Experiences," Journal of Engineering Education, 10.1002/j.2168-9830.2012.tb00048.x/full vol. 101, no. 2, pp. 187-219, 2012, doi: papers3://publication/doi/10.1002/j.2168-9830.2012.tb00048.x/full.

[38] C. M. Gray, "Informal peer critique and the negotiation of habitus in a design studio," Art, design \& communication in higher education., vol. 12, no. 2, pp. 195-209, 2013, doi: 10.1386/adch.12.2.195_1.

[39] C. Dym, A. Agogino, O. Eris, D. Frey, and L. Leifer, "Engineering design thinking, teaching, and learning," Journal of Engineering Education, vol. 94, no. 1, pp. 103-121, 2005, doi: 10.1002/j.2168-9830.2005.tb00832.x.

[40] R. S. Adams, J. Turns, and C. J. Atman, "Educating effective engineering designers: the role of reflective practice," Design Studies, 10.1016/S0142-694X(02)00056-X vol. 24, no. 3, pp. 275-294, 2003, doi: papers3://publication/doi/10.1016/S0142-694X(02)00056$\mathrm{X}$.

[41] D. A. Schön, "Knowing-in-action: The new scholarship requires a new epistemology," Change, vol. 27, no. 6, pp. 26-34, 1995.

[42] D. Schön, The Reflective Practitioner How Professionals Think in Action. Basic Books, 1984. 
[43] D. W. Shaffer et al., "Epistemic Network Analysis: A Prototype for 21st-Century Assessment of Learning," International Journal of Learning and Media, vol. 1, no. 2, pp. 33-53, 2009, doi: 10.1162/ijlm.2009.0013.

[44] B. J. Fogg, G. Cuellar, and D. Danielson, "Motivating, influencing, and persuading users," no. 7). Hillsdale, NJ: L. Erlbaum Associates Inc., 2002, pp. 133-147.

[45] B. J. Fogg, "Persuasive technology," (in English), Ubiquity, vol. 2002, no. December, pp. 1-32, Nov 16 2002, doi: 10.1145/764008.763957.

[46] G. A. Boy, "Orchestrating Human-Centered Design," Springer London ed. no. 2). London, 2012.

[47] C. M. Gray, S. Yilmaz, S. R. Daly, C. Seifert, and R. Gonzalez, "Idea Generation Through Empathy: Reimagining the 'Cognitive Walkthrough'," presented at the 122nd ASEE Annual Conference \& Exposition, Seattle, WA, June 14-17, 2015, 2015.

[48] D. A. Schon and G. Wiggins, "Kinds of seeing and their functions in designing," Design studies, vol. 13, no. 2, pp. 135-156, 1992, doi: 10.1016/0142-694X(92)90268-F.

[49] C. J. Atman, R. S. Adams, M. E. Cardella, J. Turns, S. Mosborg, and J. Saleem, "Engineering design processes: A comparison of students and expert practitioners," Journal of Engineering Education, 10.1002/j.2168-9830.2007.tb00945.x/full no. October, pp. 359-379, 2007, doi: papers3://publication/doi/10.1002/j.21689830.2007.tb00945.x/full.

[50] C. J. Atman, D. Kilgore, and A. F. McKenna, "Characterizing design learning through the use of language: a mixed-methods study of engineering designers," Journal of Engineering Education, vol. 97, no. 3, pp. 309-326, 2008.

[51] R. S. Adams, S. R. Daly, L. M. Mann, and G. Dall'Alba, "Being a professional: Three lenses into design thinking, acting, and being," Design Studies, 10.1016/j.destud.2011.07.004 vol. 32, pp. 588-607, 2011, doi: papers3://publication/doi/10.1016/j.destud.2011.07.004.

[52] C. Carmel-Gilfilen and M. Portillo, "Developmental trajectories in design thinking: an examination of criteria," Design Studies, 10.1016/j.destud.2009.06.004 vol. 31, no. 1, pp. 74-91, 2010, doi: papers3://publication/doi/10.1016/j.destud.2009.06.004.

[53] T. Brown and J. Wyatt, "Design Thinking for Social Innovation," Stanford Social Innovation Review, no. Winter, pp. 31-35, 2010, doi: papers3://publication/uuid/B2AB48D3-BCB4-4A8D-A673-478248E8F1AD.

[54] B. L. Dorie, M. E. Cardella, and G. N. Svarovsky, "Capturing the Design Thinking of Young Children Interacting with a Parent," in 2014 ASEE Annual Conference, Indianapolis, Indiana, 2014.

[55] K. Dorst, "The core of 'design thinking' and its application," Design Studies, 10.1016/j.destud.2011.07.006 vol. 32, no. 6, pp. 521-532, 2011, doi: papers3://publication/doi/10.1016/j.destud.2011.07.006.

[56] C. L. Dym, A. M. Agogino, O. Eris, D. D. Frey, and L. J. Leifer, "Engineering Design Thinking, Teaching, and Learning," (in English), Journal of Engineering Education, vol. 94, no. 1, pp. 1-18, Feb 02 2005, doi: 10.1002/j.2168-9830.2005.tb00832.x.

[57] J. Ferreira, H. Christiaans, and R. Almendra, "Design Grammar - a pedagogical approach for observing teacher and student interaction," in Design Thinking Research Symposium 10, West Lafayette, IN, 2014.

[58] S. Goldman et al., "Assessing d. learning: Capturing the Journey of Becoming a Design Thinker," in Design Thinking Research: Measuring Performance in Context, H. Plattner, 
C. Meinel, and L. Leifer Eds., (Understanding Innovation. Berlin Heidelberg: SpringerVerlag Heidelberg, 2012, ch. 1, pp. 13-33.

[59] N. Mentzer, K. Becker, and M. Sutton, "Engineering Design Thinking: High School Students' Performance and Knowledge," (in English), Journal of Engineering Education, vol. 104, no. 4, pp. 417-432, Oct 24 2015, doi: 10.1002/jee.20105.

[60] J. Kolko, "Abductive thinking and sensemaking: The drivers of design synthesis," Design issues, 10.1162/desi.2010.26.1.15 vol. 26, no. 1, pp. 15-28, 2010, doi: papers3://publication/doi/10.1162/desi.2010.26.1.15.

[61] M. Lande and L. Leifer, "Incubating engineers, hatching design thinkers: Mechanical engineering students learning design through ambidextrous ways of thinking," 2010 ASEE Annual Conference and ..., 10.1007/978-0-85729-394-7_2 2010, doi: papers3://publication/doi/10.1007/978-0-85729-394-7_2.

[62] C. J. Atman et al., "Engineering Design Education," in Cambridge Handbook of Engineering Education Research, 2013, ch. Chapter 11, pp. 201-226.

[63] N. Cross, "Designerly Ways of Knowing: Design Discipline Versus Design Science," Design issues, 10.1162/074793601750357196 vol. 17, no. 3, pp. 49-55, 2001, doi: papers3://publication/doi/10.1162/074793601750357196.

[64] S. Drew and M. Guillemin, "From photographs to findings: visual meaning-making and interpretive engagement in the analysis of participant-generated images," (in English), Visual Studies, vol. 29, no. 1, pp. 54-67, Jan 27 2014, doi: 10.1080/1472586X.2014.862994.

[65] W. R. Norman Jr., "Photography as a research tool," (in English), Visual Anthropology, vol. 4, no. 2, pp. 193-216, Jan 1991, doi: 10.1080/089494688.1991.9966560.

[66] N. Sonalkar, A. Mabogunje, and L. Leifer, "Articulation of Professional Vision in Design Review," in Analyzing Design Review Conversations, R. S. Adams and J. A. Siddiqui Eds. West Lafayette, IN: Purdue University Press, 2015, pp. 285-306.

[67] P. Ruchhoeft, R. Bannerot, and R. Kastor, "Adapting the studio critique to large capstone design courses," in American Society for Engineering Education Annual Conference \& Exposition, Salt Lake City, Utah, 2004.

[68] B. Lee, H. Maldonado, and S. R. Klemmer, "Evaluating Augmented Idea Logs for Design Education," in "Computer Science Tech Reports," Stanford University, Palo Alto, 2006. [Online]. Available: http://hci.stanford.edu/cstr/

[69] D. A. Schön, The Design Studio An Exploration of its Traditions and Potentials. London: RIBA Publications for RIBA Building Industry Trust 1985.

[70] K. Cennamo et al., "Managing the Complexity of Design Problems through Studio-based Learning," Interdisciplinary Journal of Problem-Based Learning, vol. 5, no. 2, 2011.

[71] A. C. Lewis, T. L. Sadosky, and T. Connolly, "The effectiveness of group brainstorming in engineering problem solving," IEEE Transactions on Engineering Management, vol. EM-22, no. 3, pp. 119-124, 1975, doi: 10.1109/TEM.1975.6447219.

[72] A. F. Osborn, Applied imagination: Principles and procedures of creative problemsolving, 3rd revised ed. New York: C. Scribner, 1963.

[73] D. J. Foster, T. Hays, and F. Alter, "Facing the methodological challenges of re-using previously collected data in a qualitative inquiry," Qualitative Research Journal, vol. 13, no. 1, pp. 33-48, 2013. 
[74] J. Walther, N. W. Sochacka, and N. Kellam, "Quality in Interpretive Engineering Education Research: Reflections on an Example Study," Journal of Engineering Education, vol. 102, no. 4, pp. 626-660, 2013.

[75] J. Walther and N. W. Sochacka, "Qualifying qualitative research quality (The Q3 project): An interactive discourse around research quality in interpretive approaches to engineering education research," in Frontiers in Education (FIE) Conference, Madrid, Spain, 22-25 Oct. 2014 2014, doi: 10.1109/FIE.2014.7043988.

[76] J. Walther, A. L. Pawley, and N. W. Sochacka, "Exploring Ethical Validation as a Key Consideration in Interpretive Research Quality," in 122nd American Society for Engineering Education Annual Conference and Exposition, Seattle, WA, June 14-17, 20152015.

[77] C. Cunningham, "Engineering is Elementary," The Bridge: Linking Engineering and Society, vol. 39, no. 3, pp. 11-17, 2009. 